\title{
PRODUCTION D'ACIDES GRAS A COURTE CHAINE AU COURS DE LA DIGESTION CHEZ LE PORC
}

\author{
M. ÉTIENNE \\ Station de Recherches sur l'Élevage des Porcs, \\ Centre national de Recherches zootechniques, I. N.R. A., \\ 78 - Jouy-en-Josas
}

Une expérience a été conduite sur Io porcs de race Large White, d'un poids moyen de I08 $\mathrm{kg}$, afin de mesurer, en fonction du temps écoulé après le repas, les quantités d'acides gras volatils (AGV) et d'acide lactique présentes dans les différentes parties du tube digestif. Ces animaux recevaient un régime renfermant $\mathrm{I} 2 \mathrm{p}$. Ioo de protéines de poisson, I5 $\mathrm{p}$. Ioo de cellulose de bois purifiée et $62 \mathrm{p}$. Ioo d'amidon de maïs.

Le temps écoulé après le dernier repas semble avoir peu d'influence sur la concentration en acides organiques : dans l'estomac, la concentration en acide lactique augmente jusqu'à $9 \mathrm{~h}$ après la consommation ( $\mathrm{pH}$ et microflore favorables à ce type de fermentation); il en va de même pour l'acide acétique dans le cæcum et le colon concentrique $3 \mathrm{~h}$ après le repas, au moment de son arrivée dans cette partie du tube digestif.

Les concentrations en acides rapportées au produit frais s'élèvent entre le début : $43 \mathrm{mM} / \mathrm{kg}$ et la fin du tube digestif : r ıo $\mathrm{mM} / \mathrm{kg}$ (ralentissement du transit), l'acide lactique domine jusqu'à la fin de l'intestin grêle ( 45 à 60 p. Ioo des acides totaux) ; l'acide acétique présent en grandes quantités dans tous les compartiments devient prédominant après l'intestin grêle $(72 \mathrm{p}$. roo des acides totaux). A part l'acide butyrique, et surtout l'acide propionique, dont les concentrations sont relativement élevées, les autres AGV n'apparaissent que faiblement à partir du cæcum; ces derniers pourraient provenir du catabolisme azoté. Les concentrations rapportées à la matière sèche montrent un maximum d'acides totaux au niveau du cæcum, où la teneur en eau est la plus forte $(800 \mathrm{mM} / \mathrm{kg})$. Elles sont comparables à celles observées dans le rumen des ruminants.

Le bilan des acides dans chaque compartiment met en évidence l'importance des fermentations dans le colon ( 56 p. Ioo des acides, surtout AGV) et de l'estomac ( 29 p. Ioo des acides, surtout lactique). Mais à cause du volume digestif réduit, les quantités totales restent faibles en comparaison des bovins ( $400 \mathrm{mM}$ seulement d'acides totaux).

\section{SUMMARY}

\section{PRODUCTION OF SHORT CHAIN FATTY ACIDS DURING DIGESTION IN THE PIG}

An experiment was carried out on Io Large White pigs, with an average weight of ro $\mathrm{kg}$, in order to measure the amounts of volatile fatty acids (VFA) and lactic acid in the different parts of the digestive tract, at different moments after the meal. These animals received a diet containing I 2 p. Ioo fish meal protein, 15 p. Ioo purified wood cellulose and 62 p. Ioo maize starch.

The time elapsed after the last meal seems to have only a slight influence upon the concentration of organic acids : in the stomach, the lactic acid concentration increases until 9 hours after the food intake ( $\mathrm{pH}$ and microflora being favourable to that type of fermentation); this 
is also the case for acetic acid in the caecum and colon 3 hours after the meal, when the food arrives in this part of the digestive tract.

The concentrations of acids related to the fresh product increase between the beginning : $43 \mathrm{mM} / \mathrm{kg}$ and the end of the digestive tract : I $10 \mathrm{mM} / \mathrm{kg}$ (decrease of the transit rate), lactic acid dominates until the end of the small intestine ( 45 to 60 p. roo of the total acids); acetic acid, present in great quantities overall in the digestive tract, becomes predominating after the small intestine ( 72 p. Ioo of the total acids). Except butyric acid, and especially propionic acid, the concentrations of which are relatively high, the other VFA are only present in small quantities from the level of the caecum ; the origin of the latter could be the nitrogen catabolism. The concentrations related to the dry matter show a maximum of total acids at the level of the caecum, where the water content is the most important $(800 \mathrm{mM} / \mathrm{kg})$. These concentrations are comparable to those observed in the rumen of the ruminants.

The balance of the acids in each part of the digestive tract shows the importance of the fermentations in the colon ( 56 p. Ioo of the acids, in particular VFA) and the stomach (29 p. roo of the acids, especially lactic acid). However, because the digestive volume is small, the total amounts are low in comparison with those of cattle (only $400 \mathrm{mM}$ of total acids). 